\title{
Ultrastructure of the replication site in Taura syndrome virus (TSV)-infected cells
}

\author{
Thinnarat Srisuvan ${ }^{1,2, *}$, Carlos R. Pantoja ${ }^{2}$, Rita M. Redman ${ }^{2}$, Donald V. Lightner ${ }^{2}$ \\ ${ }^{1}$ Department of Livestock Development, 69/1 Phayathai Road, Bangkok 10400, Thailand \\ ${ }^{2}$ Department of Veterinary Science and Microbiology, University of Arizona, 1117 E. Lowell, Tucson, Arizona 85721, USA
}

\begin{abstract}
Taura syndrome virus (TSV) is a member of the family Dicistroviridae that infects Pacific white shrimp Litopenaeus vannamei (also called Penaeus vannamei), and its replication strategy is largely unknown. To identify the viral replication site within infected shrimp cells, the viral RNA was located in correlation with virus-induced membrane rearrangement. Ultrastructural changes in the infected cells, analyzed by transmission electron microscopy (TEM), included the induction and proliferation of intracellular vesicle-like membranes, while the intracytoplasmic inclusion bodies and pyknotic nuclei indicative of TSV infection were frequently seen. TSV plus-strand RNA, localized by electron microscopic in situ hybridization (EM-ISH) using TSV-specific cDNA probes, was found to be associated with the membranous structures. Moreover, TSV particles were observed in infected cells by TEM, and following EM-ISH, they were also seen in close association with the proliferating membranes. Taken together, our results suggest that the membranous vesicle-like structures carry the TSV RNA replication complex and that they are the site of nascent viral RNA synthesis. Further investigations on cellular origins and biochemical compositions of these membranous structures will elucidate the morphogenesis and propagation strategy of TSV.
\end{abstract}

KEY WORDS: Taura syndrome virus · TSV · In situ hybridization · Transmission electron microscopy · Litopenaeus vannamei

\section{INTRODUCTION}

Taura syndrome (TS) is an economically important disease listed by the World Organization for Animal Health (OIE 2006). Since its first recognition in Ecuador in 1992, TS has rapidly spread to cultured penaeid shrimp-farming regions in many countries of the Americas, Asia, and Africa and has continued to devastate the shrimp industry for the last decade (Lightner et al. 1995, Nielsen et al. 2005, Srisuvan et al. 2005, Tang \& Lightner 2005). The causative agent of TS is Taura syndrome virus (TSV), a member of the family Dicistroviridae, which is a non-enveloped icosahedral virus with a diameter of $32 \mathrm{~nm}$ and a single-stranded, positive-sense RNA genome of 10205 nucleotides (Bonami et al. 1997, Mari et al. 2002, Mayo 2005). The principal host of TSV is Pacific white shrimp Litopenaeus vannamei (also called Penaeus vannamei; Lightner et al. 1995, Pérez-Farfante \& Kensley 1997).
The intracellular biogenesis of TSV remains largely uninvestigated, although the virus has been an intense subject of research for almost 15 yr. Ultrastructural pathogenesis of many viruses, e.g. human parechovirus type 1 , dengue virus, hepatitis $\mathrm{C}$ virus, foot-andmouth disease virus (FMDV), and severe acute respiratory syndrome-associated coronavirus (SARS-CoV), has been characterized using transmission electron microscopy (TEM), in situ hybridization (ISH), and immunoelectron microscopy (IEM; Grief et al. 1997, Gosert et al. 2003, Krogerus et al. 2003, Goldsmith et al. 2004, Monaghan et al. 2004). Additionally, our laboratory has previously developed an ISH protocol using a specific cDNA probe to follow the intracellular translocation of hepatopancreatic parvovirus (HPV) in penaeid shrimp (Pantoja \& Lightner 2001).

Infection by all single-stranded, positive-sense RNA viruses is believed to involve the intracellular rearrangement of membranes in the cytosol (for reviews, 
see Mackenzie 2005, Novoa et al. 2005). The host cell membranes function as the replication site for the synthesis of the nascent viral genomes. For instance, in many viruses such as mouse hepatitis virus, rubella virus, and Semliki Forest virus, these consist of generation and proliferation of endoplasmic reticulum (ER) and membrane vesicles that accumulate in the perinuclear region of infected cells (Magliano et al. 1998, Kujala et al. 2001, Gosert et al. 2002). Characterization of the viral replication complexes is an important aspect in virology and cell biology. In the present paper, the ultrastructure of the replication site in cells infected with TSV was visualized by TEM and ISH.

\section{MATERIALS AND METHODS}

Shrimp specimens. Litopenaeus vannamei were collected from affected farms in Ecuador, Peru, and Colombia, fixed in $6 \%$ glutaraldehyde in phosphate buffer, and processed for TEM as previously described by Bonami et al. (1992). Histological examinations revealed that they exhibited characteristic lesions of TSV infection as previously reported by Lightner et al. (1995) (not shown). These shrimp were not tested for TSV by ISH.

Specimens used for ISH were embedded in paraffin and hydrophilic Unicryl resin (British Bio-Cell International). For paraffin embedding, the specimen was a Litopenaeus vannamei ( $\mathrm{wt}=1 \mathrm{~g}$ ) derived from a specific-pathogen-free (SPF) Kona stock (Moss et al. 2005), obtained from the Oceanic Institute, Oahu, Hawaii, USA. This shrimp was inoculated with a tissue homogenate prepared from frozen TSV-infected $L$. vannamei, collected from Thailand in 2004 (Th04, GenBank number AY997025; for a detailed inoculation method, see Srisuvan et al. 2005). The cephalothorax was fixed with Davidson's fixative and embedded in paraffin for histological analysis using standard methods (Lightner 1996). The paraffin-embedded tissue sections were used for light microscopic (LM)-ISH.

In addition, specimens for Unicryl resin embedding were generated in experimental challenge studies using 20 SPF Kona Litopenaeus vannamei (average $\mathrm{wt}=1 \mathrm{~g})$. Each shrimp was administered a single injection $(\sim 100 \mu \mathrm{l})$, into the third tail segment, of a tissue homogenate prepared from frozen TSV-infected $L$. vannamei, collected from Belize in 2001 (Bz01, GenBank number AY590471). The tissue homogenate was prepared from shrimp cephalothoraxes as described by Hasson et al. (1995), and diluted 1:150 with 2\% saline prior to inoculation. All shrimp were fed once a day with a commercial pelleted feed (Rangen 35\%, Buhl), starting at Day 0 post-inoculation (p.i.). The aquarium was observed twice a day for moribund and dead shrimp. The gills of 11 moribund shrimp, sampled at Days 3 to 5 p.i., were processed for both LM-ISH and electron microscopic (EM)-ISH as subsequently described.

Fixation, embedding, and sectioning for ISH. The fixative was $6 \%$ glutaraldehyde prepared with $0.15 \mathrm{M}$ Millonig's phosphate buffer ( $\mathrm{pH}$ 7.0) supplemented with $1 \%$ sodium chloride and $0.5 \%$ sucrose. The gills of each TSV-infected shrimp were collected and cut into small pieces $\left(\sim 1 \mathrm{~mm}^{3}\right)$ in ice-cold phosphate buffer. Tissue specimens from each shrimp were transferred to the ice-cold fixative, $\sim 10 \times$ the volume of the shrimp tissues $(\sim 1 \mathrm{ml})$, and fixed for $6 \mathrm{~h}$ under refrigeration $\left(4^{\circ} \mathrm{C}\right)$.

After fixation, specimens were dehydrated at room temperature $\left(\mathrm{RT}, \sim 25^{\circ} \mathrm{C}\right.$ ) in a graded series of ethanol (15 min each in 30, 50, 70, 80, and $95 \%$, and twice in absolute ethanol). The dehydrated specimens were infiltrated at $4^{\circ} \mathrm{C}$ with increasing concentrations of Unicryl resin as follows: $24 \mathrm{~h}$ in resin:absolute ethanol (1:2), $24 \mathrm{~h}$ in resin:absolute alcohol (2:1), and $24 \mathrm{~h}$ in pure resin. Resin-infiltrated specimens were transferred into Beem capsules containing fresh resin and polymerized at $-10^{\circ} \mathrm{C}$ for $5 \mathrm{~d}$ by exposure to ultraviolet (UV) light provided by $2 \times 15 \mathrm{~W}$ Phillips UV lamps, $360 \mathrm{~nm}$ wavelength, set at approximately $15 \mathrm{~cm}$ under the Beem capsules.

Semi-thin sections (1 $\mu \mathrm{m}$ thickness) were placed on a drop of high performance liquid chromatography (HPLC) water on a microscope glass slide, heat-dried at $60^{\circ} \mathrm{C}$ for $\sim 2 \mathrm{~min}$, stained with $0.5 \%$ toluidine blue in $1 \%$ sodium borate at $60^{\circ} \mathrm{C}$ for $1 \mathrm{~min}$, and then observed with a light microscope for the presence of characteristic lesions of TSV infection as described by Lightner et al. (1995). Consecutive semi-thin sections were placed on drops of HPLC water on Superfrost/ Plus positively charged microscope slides (Fisher Scientific), heat-dried, and stored at RT until the time of analysis. Five slides of semi-thin sections were prepared from each block. Five to 7 consecutive ultra-thin sections (gold interference color) from the same blocks were also placed on carbon/Formvar-coated 100-mesh nickel grids and stored, unstained, at RT.

Preparation of TSV-specific cDNA probes. A mixture of the probes TS624 and TS622 was used for ISH (Srisuvan et al. 2006). Probes TS624 and TS622 hybridize with the TSV genome (GenBank number AF277675) at nucleotides 3218 to 3841 and 5899 to 6520 , respectively. They were prepared from 2 cDNA clones, TSV837-5575 and TSV5049-10205, respectively, by polymerase chain reaction (PCR) labeling with digoxigenin (DIG)-11-dUTP as described by Mari et al. (1998). Primers 3218F (5'-CAC TAC GTT AGC AGG CAA TG-3') and 3841R (5'-CAC TTC ACT GCA CTC GAC AC-3') were used to label probe TS624 
(624 bp), while primers 5899F (5'-TTA AGC GCG TTG GTG ACA AG-3') and 6520R (5'-GCA TCC TGC GCA TCG ATA TT-3') were used to label probe TS622 (622 bp). The reaction mixture contained $5 \mu \mathrm{l}$ of an appropriate cDNA clone, $10 \mu \mathrm{l}$ of $10 \times$ PCR buffer (Applied Biosystems), $100 \mu \mathrm{M}$ of dTTP, $100 \mu \mathrm{M}$ of a mixture of dATP, dCTP, and dGTP, $10 \mu \mathrm{l}$ of 10× DIG-DNA labeling mix (Roche), $2 \mathrm{mM}$ of $\mathrm{MgCl}_{2}, 1 \mathrm{mM}$ each of forward and reverse primers, and 0.05 unit of AmpliTaq Gold DNA Polymerase in a final volume of $100 \mu \mathrm{l}$. The PCR profile was 5 min at $94^{\circ} \mathrm{C}$, followed by 40 cycles of $94^{\circ} \mathrm{C}$ for $1 \mathrm{~min}, 55^{\circ} \mathrm{C}$ for $1 \mathrm{~min}, 72^{\circ} \mathrm{C}$ for $2 \mathrm{~min}$, and a final extension step at $72^{\circ} \mathrm{C}$ for $7 \mathrm{~min}$. An aliquot of each DIG-labeled probe, TS624 and TS622, was analyzed in $1 \%$ agarose gel containing ethidium bromide. Following $\mathrm{PCR}$, each probe $(\sim 99 \mu \mathrm{l})$ was precipitated with $360 \mu \mathrm{l}$ of absolute ethanol, containing $1 \mu \mathrm{l}$ of $20 \mathrm{mg}$ $\mathrm{ml}^{-1}$ glycogen, $10 \mu \mathrm{l}$ of $200 \mathrm{mM}$ EDTA (pH 8.0), and $11 \mu \mathrm{l}$ of $4 \mathrm{M} \mathrm{LiCl}$. The probe suspension was mixed well, placed at $-20^{\circ} \mathrm{C}$ overnight $(\sim 16 \mathrm{~h})$, and centrifuged at $4^{\circ} \mathrm{C}$ and $13000 \times g$ for $30 \mathrm{~min}$. The supernatant was carefully decanted, and the pellet was washed with $0.5 \mathrm{ml}$ of cold $70 \%$ ethanol, followed by centrifugation for $10 \mathrm{~min}$ at $4^{\circ} \mathrm{C}$ and $13000 \times g$. The supernatant was decanted, and the pellet was air-dried for $20 \mathrm{~min}$. Finally, each probe was re-suspended in $100 \mu \mathrm{l}$ of HPLC water, placed at $37^{\circ} \mathrm{C}$ for $10 \mathrm{~min}$, and stored at $-20^{\circ} \mathrm{C}$.

LM-ISH. Paraffin and Unicryl resin-embedded tissue sections of Litopenaeus vannamei were used for LMISH. For paraffin-embedded specimens, the hybridization procedure was identical to that of resin-embedded sections as subsequently described, except for the counterstaining. Specifically, after the silver enhancement step, slides were counterstained for $5 \mathrm{~min}$ with $0.5 \%$ Bismarck Brown (Science Lab) and dehydrated as follows: $3 \times 10$ dips each in $95 \%$, absolute ethanol, and $4 \times 10$ dips in Clear-Rite (Richard-Allan Scientific). The slides were then mounted with Permount (Fisher Scientific) and examined under a light microscope. The hybridization using only hybridization buffer without the TSV-specific gene probes was also performed on appropriate slides (negative control).

For Unicryl resin-embedded tissue sections, the hybridization protocol was modified from a protocol that was developed for HPV (Pantoja \& Lightner 2001). Specifically, semi-thin sections were first re-hydrated at RT for 10 min each with HPLC water and $1 \times$ TNE (50 mM Tris- $\mathrm{HCl}, 10 \mathrm{mM} \mathrm{NaCl}, 1$ mM EDTA, pH 7.4). Proteolytic digestion was performed in a humid incubator at $37^{\circ} \mathrm{C}$ for $15 \mathrm{~min}$ with $500 \mu \mathrm{l}$ of $100 \mu \mathrm{g} \mathrm{ml}{ }^{-1}$ freshly prepared Proteinase K (Sigma Chemical) diluted in $1 \times$ TNE. The digestion was inactivated for $5 \mathrm{~min}$ in $0.4 \%$ cold formaldehyde, and the sections were rinsed for 5 min at RT with $2 \times$ standard saline cit- rate $(\mathrm{SSC}, 1 \times=0.15 \mathrm{M} \mathrm{NaCl}, 0.015 \mathrm{M}$ sodium citrate, $\mathrm{pH}$ 7.0). Pre-hybridization was performed by pouring $200 \mu \mathrm{l}$ of hybridization buffer ( $50 \%$ formamide, $0.02 \%$ Ficoll 400, $0.02 \%$ polyvinylpyrolydone $360, \quad 0.02 \%$ bovine serum albumin, $5 \%$ dextran sulfate, $0.5 \mathrm{mg}$ $\mathrm{ml}^{-1}$ denatured salmon sperm DNA, $4 \times \mathrm{SSC}$ ) onto the slides, which were then incubated in a humid incubator at $37^{\circ} \mathrm{C}$ for $30 \mathrm{~min}$. Denatured probes were prepared by adding $2 \mu \mathrm{l}$ each of probes TS622 and TS624 to $500 \mu \mathrm{l}$ of hybridization buffer. The mixture of probes was then boiled at $100^{\circ} \mathrm{C}$ for $10 \mathrm{~min}$ and quenched on ice for $5 \mathrm{~min}$. The denatured probes $(100 \mu \mathrm{l})$ were placed onto each slide, and slides were incubated overnight $(\sim 20 \mathrm{~h})$ in a humid incubator at $37^{\circ} \mathrm{C}$.

The resin sections were subjected to post-hybridization washes with decreasing concentrations of SSC at $37^{\circ} \mathrm{C}(2 \times 5$ min each in $2 \times, 1 \times, 0.5 \times$, and $0.1 \times \mathrm{SSC})$. The slides were soaked in Buffer I $(0.1 \mathrm{M}$ Tris-HCl, $0.15 \mathrm{M} \mathrm{NaCl}, \mathrm{pH} 7.5$ ) at $37^{\circ} \mathrm{C}$ for $5 \mathrm{~min}$ and blocked at $37^{\circ} \mathrm{C}$ for 15 min with $125 \mu \mathrm{l}$ of Buffer II (blocking buffer, $0.5 \mathrm{ml}$ of $10 \mathrm{mg} \mathrm{ml}^{-1}$ Blocking reagent [Roche] in Buffer I). Detection of the hybridized probes was performed using a sheep anti-DIG antibody conjugated with $15 \mathrm{~nm}$-colloidal gold particles (Electron Microscopy Sciences), diluted 1:50 in Buffer II. The slides were incubated in a humid incubator at $37^{\circ} \mathrm{C}$ for $2 \mathrm{~h}$. Gold particles not bound to the probes were extensively washed $4 \times 5$ min each with Buffer I and HPLC water at RT. Amplification of the reacted gold particles was performed using a silver enhancer (Electron Microscopy Sciences), which was placed onto each slide $(0.5 \mathrm{ml})$, and slides were incubated for $15 \mathrm{~min}$ in a dark humid chamber at RT. The silver enhancement was terminated in HPLC water for 15 min at RT. Slides were heat-dried at $60^{\circ} \mathrm{C}$ for $1 \mathrm{~min}$, counterstained for $30 \mathrm{~s}$ with $0.5 \%$ toluidine blue in $1 \%$ sodium borate, mounted with Permount, and examined under a light microscope.

EM-ISH. Ultra-thin sections of resin-embedded specimens were processed for electron microscopy. The hybridization procedures were almost identical to those developed for LM-ISH. All reagents were placed as a drop ( $25 \mu \mathrm{l}$ ) on a piece of hydrophobic film, and grids containing tissue sections were floated on the drops with the section side facing down, while reagents destined for incubation were placed on a hydrophobic film in a Petri dish with a moistened filter paper in the bottom. Grids were rehydrated for $5 \mathrm{~min}$ each in HPLC water and $1 \times \mathrm{TNE}$, and incubated with Proteinase $\mathrm{K}$ for $5 \mathrm{~min}$. The reaction was inactivated in cold formaldehyde for $5 \mathrm{~min}$. The grids were washed for $5 \mathrm{~min}$ at RT in $2 \times \mathrm{SSC}$ and pre-hybridized in hybridization buffer for $30 \mathrm{~min}$. Hybridization was performed overnight $(\sim 20 \mathrm{~h})$ at $37^{\circ} \mathrm{C}$ in a humid incubator on drops of a mixture of denatured probes TS622 and TS624. 
Post-hybridization washes followed the above procedures, and the grids were blocked in Buffer II for $15 \mathrm{~min}$ at $37^{\circ} \mathrm{C}$. The detection of probes was performed for $2 \mathrm{~h}$ at $37^{\circ} \mathrm{C}$ using the anti-DIG gold conjugated antibody $(20 \mu \mathrm{l})$. Grids were rinsed $4 \times 5 \mathrm{~min}$ each in Buffer I and HPLC water. Silver enhancement was performed by floating the grids on a drop $(20 \mu \mathrm{l})$ of the silver enhancer in a dark humid chamber at RT for $15 \mathrm{~min}$. The reaction was stopped by floating the grids on a drop of HPLC water for 15 min followed by airdrying on a piece of filter paper for at least $3 \mathrm{~h}$.

Counterstaining was performed using uranyl acetate (UA) and lead citrate (LC) according to Morel et al. (2001). Specifically, for UA staining a grid was floated on a drop of $5 \%$ aqueous UA $(30 \mu \mathrm{l})$ with the tissue section facing down, and incubation was performed in the dark for $30 \mathrm{~min}$. The grid was swirled for $10 \mathrm{~s}$ in a beaker of HPLC water and air-dried for $30 \mathrm{~min}$ on a piece of filter paper in a Petri dish. For LC staining, a drop of $10 \%$ LC (30 $\mu$ l) was placed on hydrophilic film in a Petri dish in which a pellet of $\mathrm{NaOH}$ had been placed for $3 \mathrm{~min}$ to capture carbon dioxide. Then, a grid was floated on the drop with the tissue section facing down for $5 \mathrm{~min}$, washed, and air-dried as described for UA. EM analysis in this study was performed using a JEOL 100CXII model at the University of Arizona.

\section{RESULTS}

\section{TEM}

The ultrastructure of cells infected with TSV was first characterized by TEM. Structural changes of TSVinfected cells were classified into 3 stages: early, mid, and late stages of TSV infection. The morphological identities of cells at the early stages of infection were the accumulation of cytoplasmic organelles, including rough ER (RER), Golgi that had a normal stacked appearance, and mitochondria, in the perinuclear region of the cells (Fig. 1). Also at this stage of infection, intracellular inclusion bodies, indicative of TSV

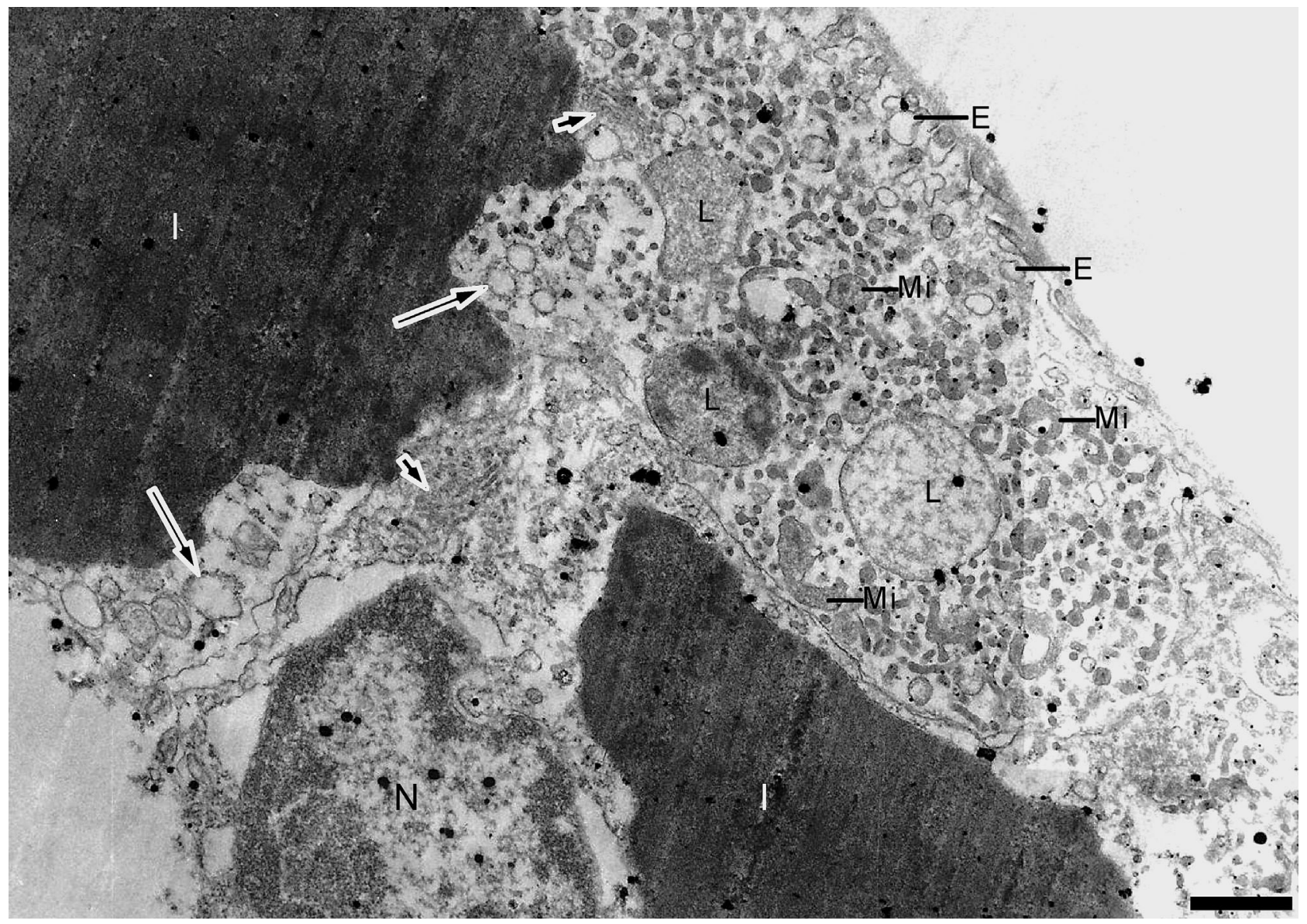

Fig. 1. Litopenaeus vannamei. Ultrastructural changes in cells at early stages of infection with Taura syndrome virus (TSV). The nucleus (N) exhibits a normal appearance. The cytoplasmic organelles, including Golgi (short arrows), rough endoplasmic reticulum (RER, long arrows), and mitochondria (Mi) can be seen in the perinuclear region. Also shown in the cytoplasm are large electron-dense inclusion bodies (I), endocytic vacuoles $(\mathrm{E})$, and lysosomes $(\mathrm{L})$. Scale bar $=0.5 \mu \mathrm{m}$ 
infection, were occasionally seen in the perinuclear region, while the nuclei usually exhibited the normal appearance.

At the mid-stages of an acute phase infection, the majority of cells developed a large number of RER that had occupied a significant proportion of the cytoplasm, while the nuclei remained largely normal (Fig. 2a). The intracellular inclusion bodies were also seen in the

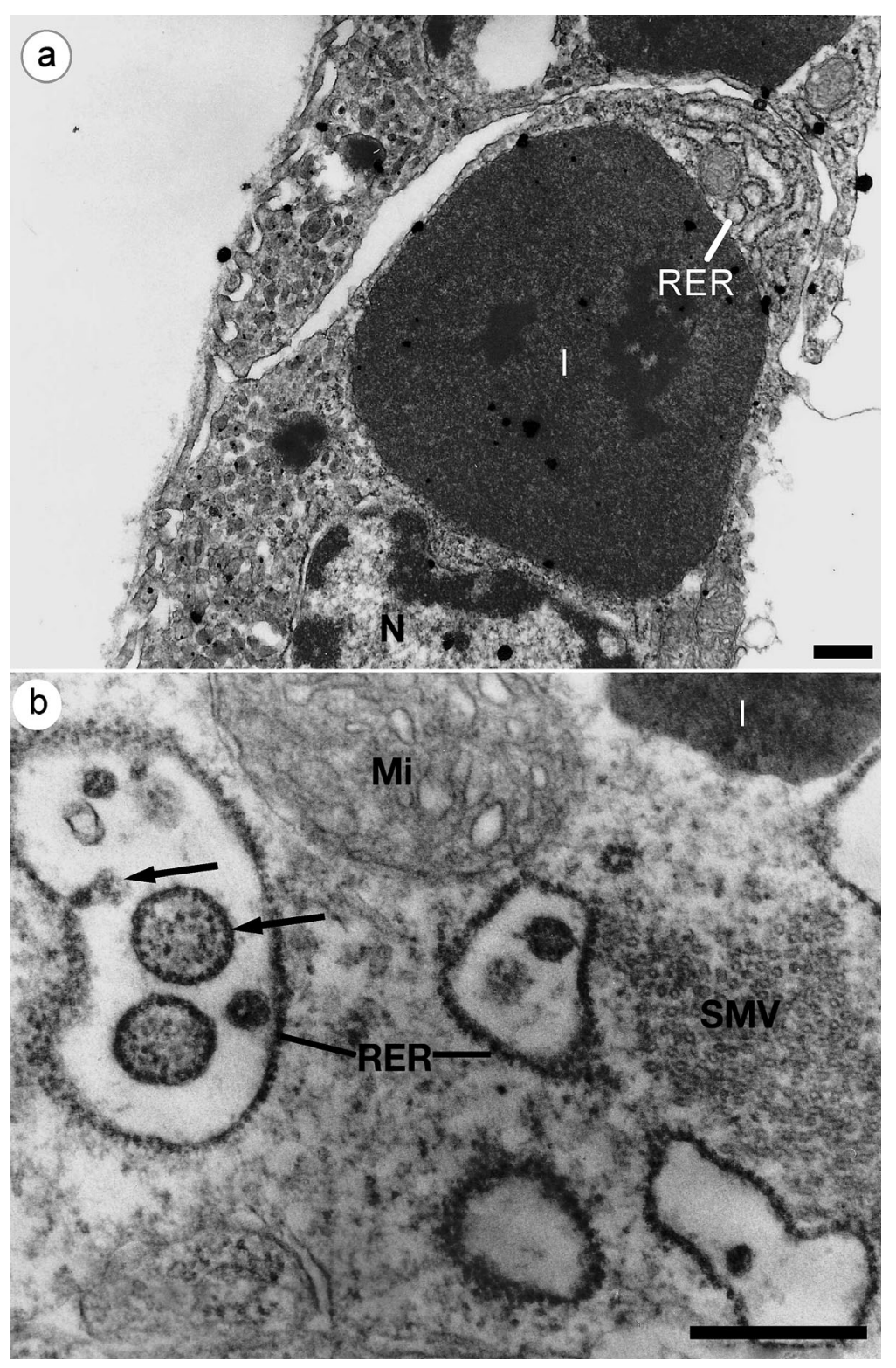

Fig. 2. Litopenaeus vannamei. Ultrastructural changes in cells at the midstages of an acute phase infection with Taura syndrome virus (TSV). (a) The nucleus $(\mathrm{N})$ displays a normal appearance, while the cytoplasm contains a large number of rough endoplasmic reticulum (RER) and intracellular inclusion bodies (I). (b) Higher magnification of an equivalent region shows that the cytosol contains clusters of developing small membranous vesicles (SMVs), distended mitochondria (Mi), and RER that are covered by small invaginations (arrows) studded with electron-dense particles. Scale bars $=0.5 \mu \mathrm{m}$ perinuclear region of infected cells. Various organelles, including RER, vesicles, and mitochondria filled the rest of the cytoplasm. Some of the mitochondria were rounded and slightly distended (Fig. 2b). More importantly, clusters of developing small membranous vesicles (SMVs) were seen within the cytosol. The RER contained electron-dense materials and were usually adjacent to SMVs. The inner surfaces of RER were sometimes covered by small invaginations.

At the late stages of infection, a significant number of intracellular membranes, i.e. RER and SMVs, and free ribosomes occupied the large proportion of the cytosol that was virtually devoid of other cytoplasmic organelles (Fig. 3). The RER contained electron-dense materials, while the rest of the cytoplasm was also filled with electron-dense particles. Some RER were contiguous with the outer membrane of the nucleus, which usually displayed a pyknotic appearance, indicative of TSV infection. More interestingly, TSV particles seen as spherical bodies were observed within the cytoplasm of cells at late stages of infection (Fig. 4). Again, the cells had lost all cytoplasmic organelles and largely reduced in volume. It is also worth noting that the pyknotic nuclei of TSVinfected cells were eccentric on one side of the cells; these results determined by TEM are in accordance with those by EM-ISH illustrated later in Figs. 7 to 9.

\section{LM-ISH}

Hybridization by TSV-specific cDNA probes was first investigated by light microscopy using paraffin-embedded tissue sections of TSV-infected shrimp. Hybridization signals were visualized using a sheep anti-DIG antibody conjugated to $15 \mathrm{~nm}$-colloidal gold particles. Black precipitates indicative of the presence of the TSV RNA genomes were observed in various epithelial tissues, including gills, cuticular, and stomach epithelia (Fig. 5a). Weak labeling signals were also seen within antennal glands and lymphoid organs (not shown). Background labeling caused by a non-specific deposition of silver was detected, but it was not associated with TSV-infected cells. No labeling was observed in tissues that were treated only 


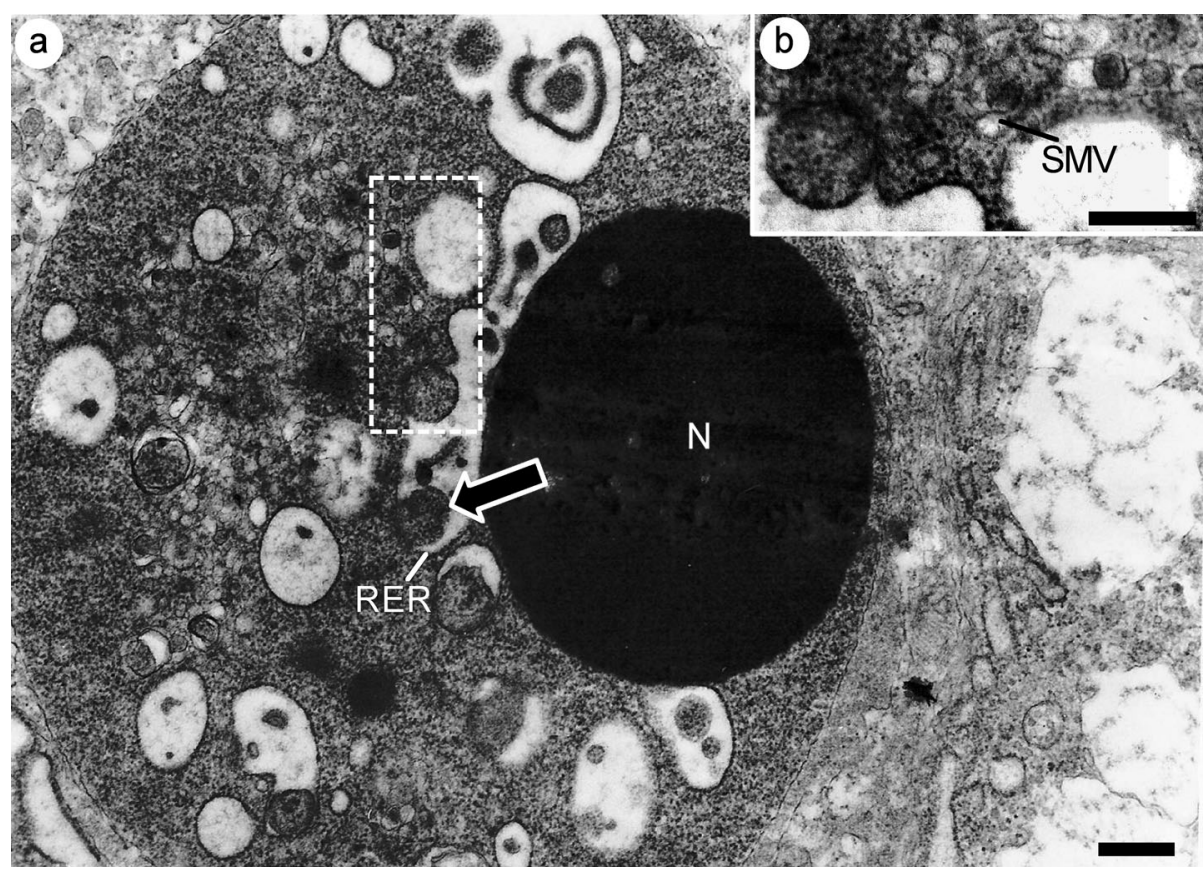

Fig. 3. Litopenaeus vannamei. Ultrastructural changes in cells at late stages of infection with Taura syndrome virus (TSV). (a) The pyknotic nucleus $(\mathrm{N})$ is surrounded by vesicular distribution of the nuclear membrane. The cytoplasm contains a large number of small membranous vesicles (SMVs) and rough endoplasmic reticulum (RER) that carry electron-dense materials (arrow).

(b) Higher magnification of the rectangular area in (a), rotated by $90^{\circ}$, shows SMVs and RER. Scale bars $=0.5 \mu \mathrm{m}$

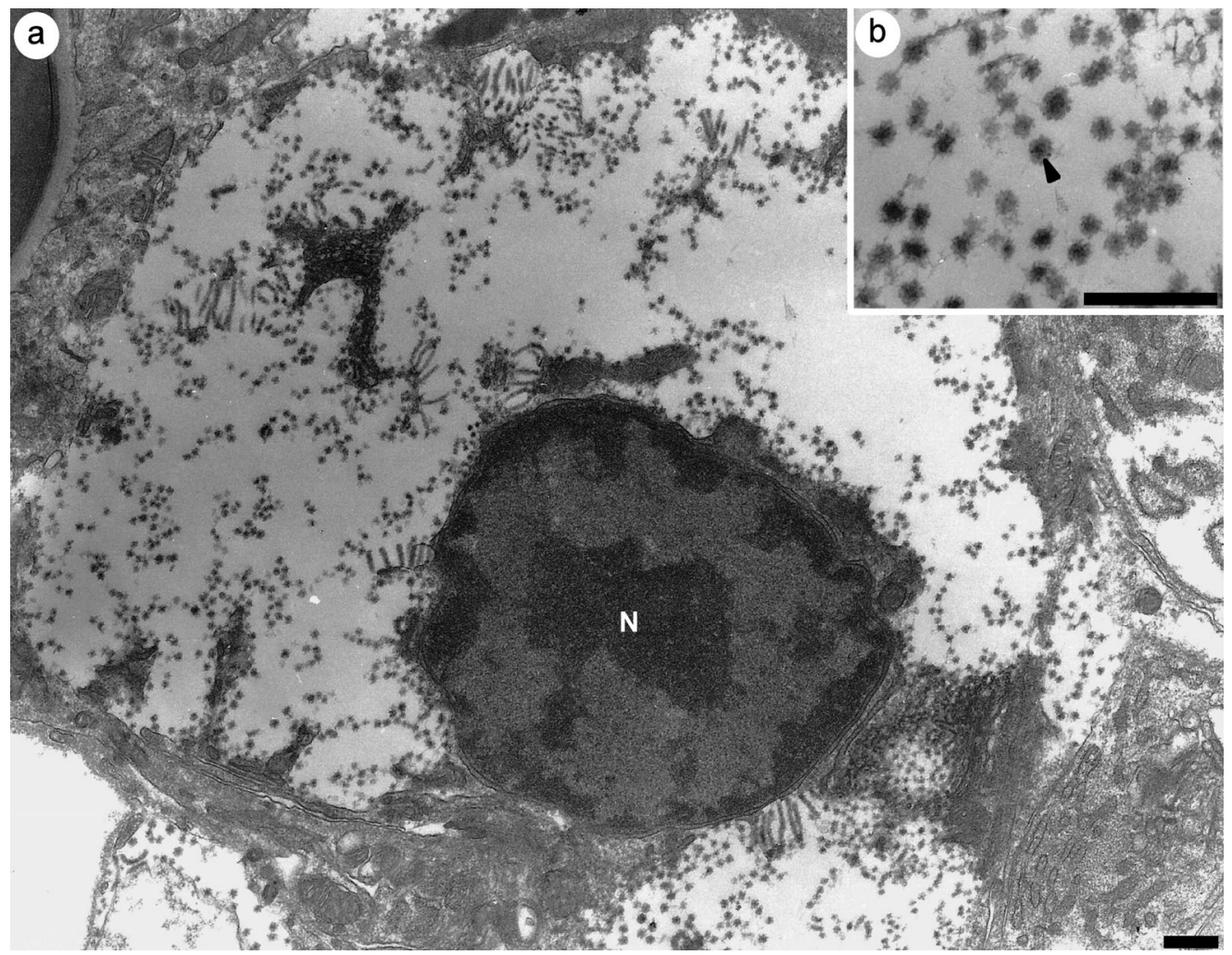

Fig. 4. Litopenaeus vannamei. Transmission electron micrographs of Taura syndrome virus (TSV) in an infected cell. At (a) low and (b) high magnifications, the nucleus ( $\mathrm{N}$ in a) shows developing pyknosis as indicated by increased electron density of the nucleoplasm, while TSV particles (arrowhead in b) are present in the cytoplasm. Scale bars $=0.5 \mu \mathrm{m}$ 


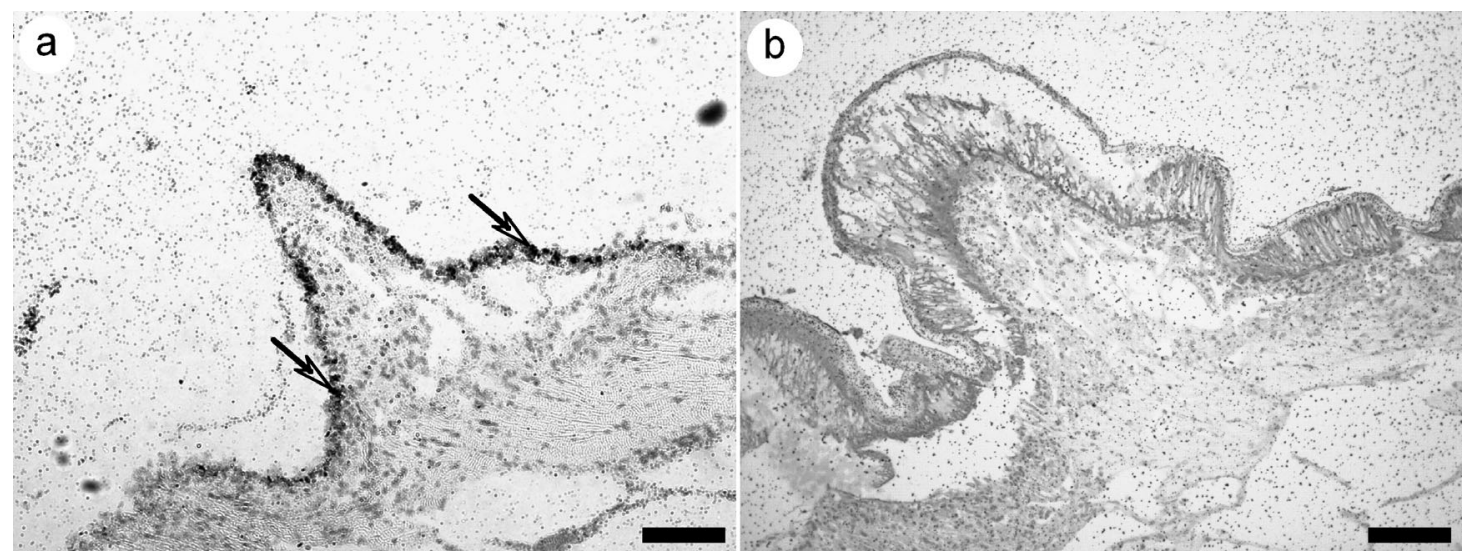

Fig. 5. Litopenaeus vannamei. Detection of Taura syndrome virus (TSV) with in situ hybridization (ISH) in paraffin-embedded tissues by light microscopy. (a) The cuticular epithelium of the stomach displays a positive hybridization reaction (arrows) to TSV-specific cDNA probes using an anti-digoxigenin antibody coupled with $15 \mathrm{~nm}$-colloidal gold particles. (b) Negative control. Scale bars $=50 \mu \mathrm{m}$

with hybridization buffer without the TSV-specific gene probes (negative control; Fig. 5b).

The positive reaction to the TSV-specific cDNA probes was also seen on semi-thin sections of Unicryl resin-embedded tissues. Epithelial cells of the gills displayed strong labeling with the TSV-specific gene probes (Fig. 6). The hybridization signals appeared almost exclusively within the cytoplasm of infected cells. Pyknotic and/or karyorrhectic nuclei and intracytoplasmic inclusion bodies could also be seen within TSV-infected cells. Additionally, ordered membranous structures, which may be derived from degenerated distended mitochondria, were observed in the cytosol (Fig. 6b; see also Figs. $7 \& 8$ ).
The intensity of the hybridization signal on resinembedded tissue sections was further investigated and optimized. Additional testing revealed that the labeling intensity can be significantly increased during 3 steps: (1) probe detection, (2) blocking, and (3) silver-enhancing steps (not shown). More specifically, hybridization yielded the best signal intensity with the anti-DIG antibody at a dilution of 1:50, followed by incubation for 15 min each with blocking buffer and silver enhancer. Moreover, non-specific deposition of silver occurred frequently when the incubation time exceeded $30 \mathrm{~min}$. The optimized time and concentration were restrictedly applied for EM-ISH.
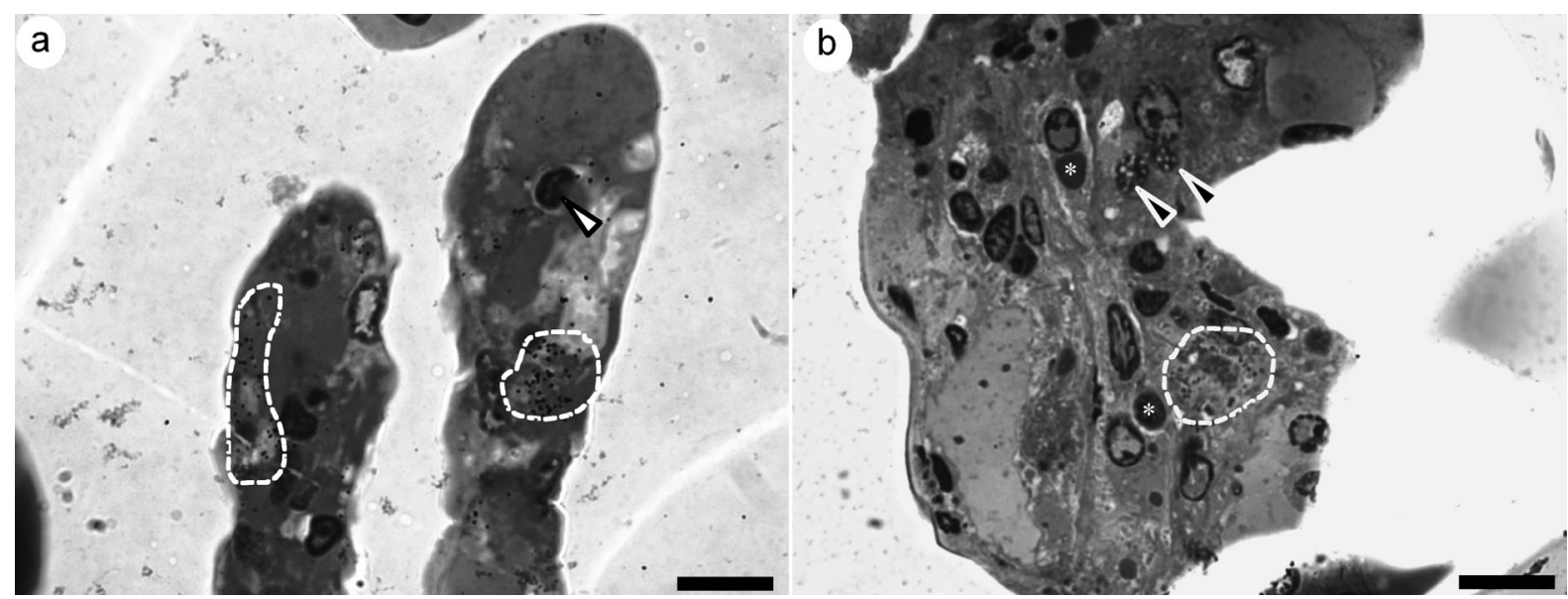

Fig. 6. Litopenaeus vannamei. Detection of Taura syndrome virus (TSV) with in situ hybridization (ISH) in resin-embedded tissues by light microscopy. (a) Gill filaments; (b) cross section of gill central axis. TSV RNA is detected by TSV-specific cDNA probes with an anti-digoxigenin antibody coupled to $15 \mathrm{~nm}$-colloidal gold particles (dashed circles). Also note that TSV-infected cells display pyknotic nuclei (white arrowhead in a) and cytoplasmic inclusion bodies (asterisks in b) and contain unknown membranous structures, which may be distended degenerated mitochondria (black arrowheads in b). Scale bars $=25 \mu \mathrm{m}$ 


\section{EM-ISH}

Hybridization signals to the TSV-specific cDNA probes were also observed by EM in ultra-thin tissue sections of resin-embedded tissues. TSV-infected cells of the gill epithelium could be identified because they specifically reacted to the hybridized probes seen as black precipitates. Their nuclei, which were relatively free of hybridization signals, showed pyknosis that is characteristic to late stages of TSV infection (Fig. 7). Unidentified membranous structures, which may have been derived from distended degenerated mitochondria as illustrated by light microscopy (Fig. 6b), were also visualized in the cytoplasm by EM (Fig. 7a). A positive reaction to the TSV-specific gene probes was also detected within circulating cells in the hemocoel (Fig. 7c); these cells may be hemocytes or necrotic cells that sloughed from the gill epithelium or stromal matrix. In addition, the nuclei of cells that had lost much of their cytoplasmic contents, found in the hemo- coel, displayed a very weak positive reaction by ISH (Fig. 7d). We also noted a positive reaction by ISH in between the inner and outer nuclear membranes (Figs. 7a,c, also see Figs. 8a,c, \& 9); however, higher magnification revealed that this region did not contain TSV-like particles.

Cells infected with TSV displayed the membrane rearrangement within the cytoplasm. A positive reaction to the TSV-specific gene probes was restricted to the cytosol, confirming that it is the replication site of the new virus progenies as suggested and illustrated in Figs. 1 to 4 by TEM. Specifically, a large number of RER and SMVs were dispersed throughout the cytosol of TSV-infected cells (Fig. 8a,b). The RER were frequently juxtaposed to mitochondria and showed continuity to the outer nuclear membrane (Fig. 8a,c). There was also some evidence of small invaginations and electron-dense materials within these membranous structures; more intriguingly, the small invaginations found on the inner surfaces of the RER displayed a
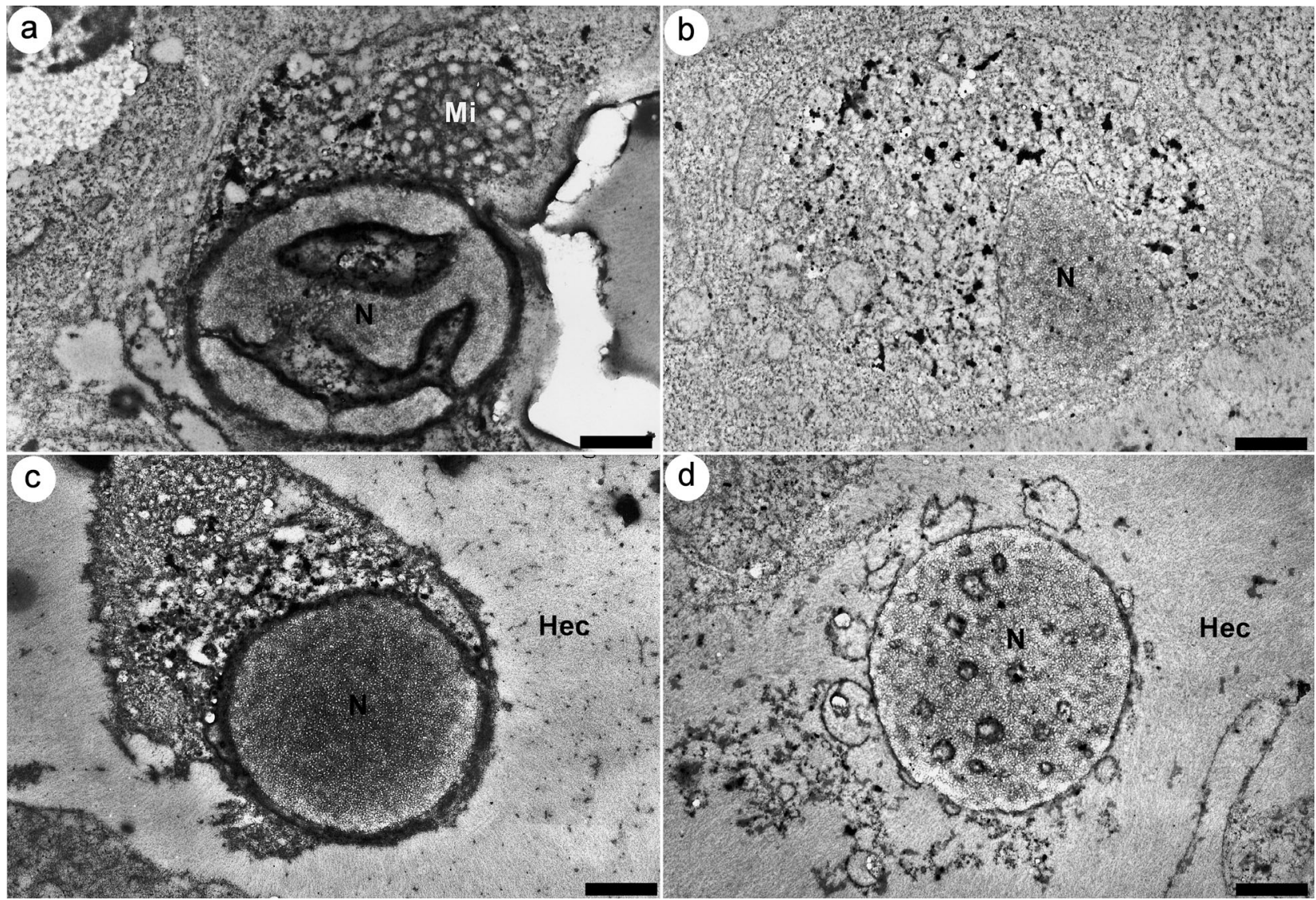

Fig. 7. Litopenaeus vannamei. Ultrastructural features of cells at late stages of Taura syndrome virus (TSV) infection examined by in situ hybridization (ISH) using TSV-specific cDNA probes. Infected cells in the gills are highly vacuolated and display strong $(\mathrm{a}-\mathrm{c})$ to weak (d) labeling signals within the cytoplasm, while the nuclei $(\mathrm{N})$ are completely devoid of signal. Also note (a) an unknown membranous structure, which may be degenerated distended mitochondrion (Mi); (c) an epithelial cell undergoing a sloughing process found in the hemocoel $(\mathrm{Hec}) ;(d)$ a nucleus with juxtaposed vacuoles and few cytoplasmic contents from a cell that had been separated from the gill epithelium. Scale bars $=1 \mu \mathrm{m}$ 

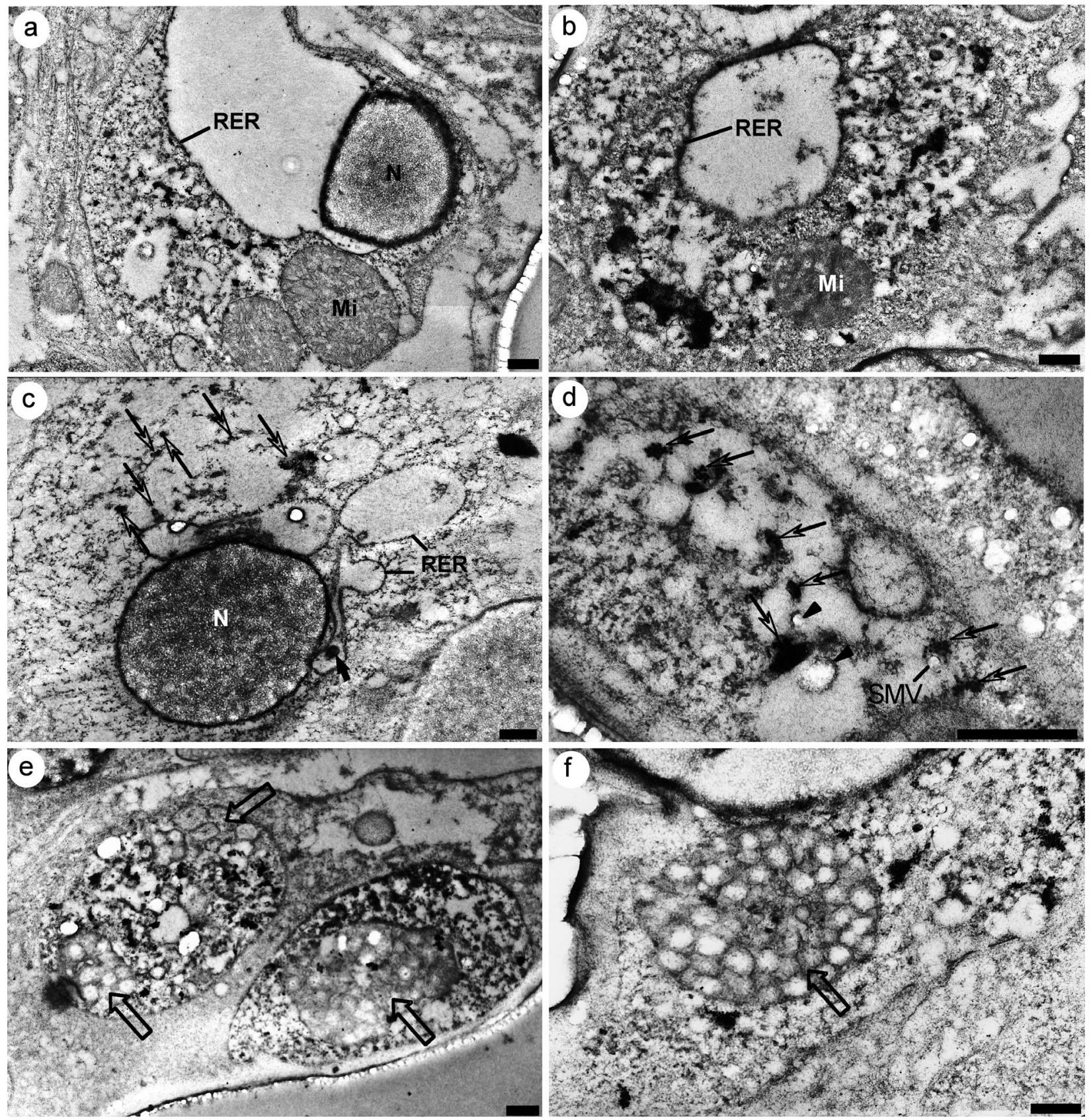

Fig. 8. Litopenaeus vannamei. Ultrastructural features of membrane rearrangement in Taura syndrome virus (TSV)-infected cells from gills analyzed by in situ hybridization (ISH) using TSV-specific cDNA probes. (a) Infected cell illustrating a pyknotic nucleus (N) and contiguous rough endoplasmic reticulum (RER) that is presumably connected to mitochondria (Mi). (b) Higher magnification of an equivalent region within the cytosol that is highly vacuolated. (c, d): Positive reaction by ISH (arrows) within RER (c) and small membranous vesicles (SMVs in d). Also indicated are electron-dense materials (short arrow in c) and SMVs unbound to gold particles (arrowheads in d). (e, f): Unknown membranous structures (clear arrows) that may be derived from distended degenerated mitochondria and which are relatively devoid of hybridization signals. (e) Randomly organized membranes are located within inclusion bodies. (f) Higher magnification of Fig. 7 a displays uniformly organized membranes in the perinuclear area. Scale bars $=0.5 \mu \mathrm{m}$

positive reaction to the TSV-specific gene probes (Fig. 8c,d). Intracellular inclusion bodies were also demonstrated by EM-ISH; they comprised SMVs and unclassified membranous structures (Fig. 8e). The
SMVs observed within the inclusion bodies did react to the TSV-specific gene probes by ISH. In contrast, the unclassified membranous structures that may be derived from distended degenerated mitochondria, 
sometimes seen in the perinuclear region, exhibited a relatively weak reaction to the TSV-specific gene probes when compared to the developing replication sites (Fig. 8e,f).
Electron-dense spherical bodies, or spherules approximately $30 \mathrm{~nm}$ in diameter when compared to 15-nm gold particles, were observed in the cytoplasm of TSV-infected cells (Fig. 9a). More interestingly, the
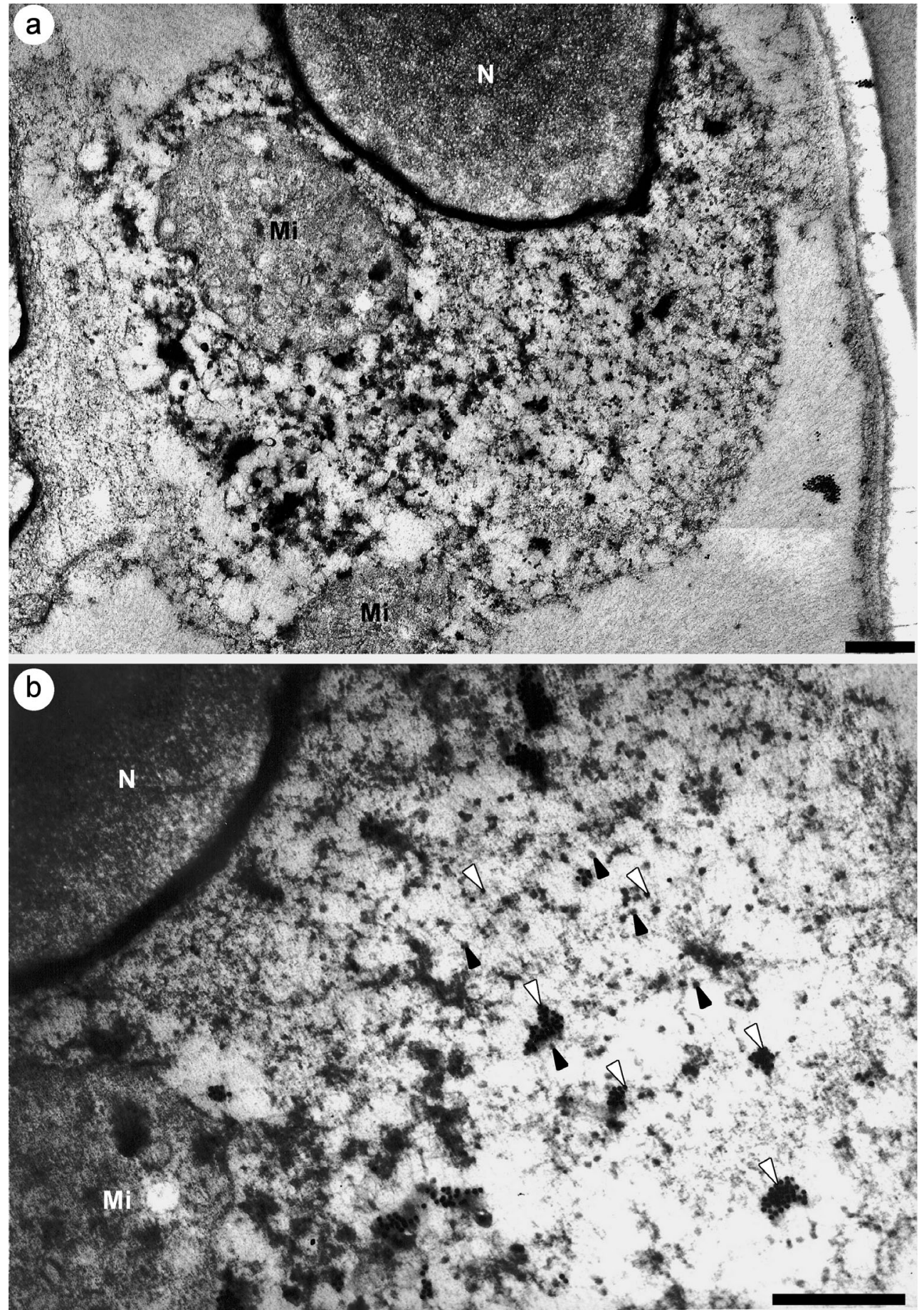

Fig. 9. Litopenaeus vannamei. Ultrastructural visualization of Taura syndrome virus (TSV) in an infected cell tested by in situ hybridization (ISH) using TSV-specific cDNA probes. The same cell from gill epithelium is shown at (a) low and (b) high magnifications. Gold particles (15 nm, white arrowheads in b), indicative of the TSV RNA genomes, are closely associated with TSV particles seen as electron-dense spherical bodies (approximately $30 \mathrm{~nm}$ in diameter, black arrowheads in b). Pyknotic nucleus (N) and mitochondria (Mi) are also indicated. Scale bars $=0.5 \mu \mathrm{m}$ 
gold particles, indicative of the presence of the TSV RNA genomes, were seen in close association with the spherical bodies on the proliferating membranes (Fig. 9b). These findings strongly suggest that the spherical bodies were the TSV particles. Moreover, the infected epithelial cells usually contained a large number of replication sites within the cytoplasm, and occasionally they were undergoing a sloughing process since they were almost excluded from intercellular matrices, reduced in volume, and had relatively fewer cytoplasmic organelles when compared to uninfected cells.

\section{DISCUSSION}

Replication of all single-stranded positive-sense RNA viruses is thought to be tightly linked to the rearrangement of cellular membranes that ultimately wrap around the viral replication complexes (Mackenzie 2005). We observed several ultrastructural features that are hallmarks of the membrane rearrangement by TEM. At early to late stages of TSV infection, cellular organelles such as RER appeared to cluster within the perinuclear region, while mitochondria were largely seen at the periphery of infected cells (Figs. 1, 2, \& 3). Eccentricity of the nuclei as illustrated in Figs. 3, 4, \& 6 to 9 also suggests that the viral replication takes place exclusively on one side of the cells. In cells infected by bunyaviruses, FMDV, and SARS-CoV, ultrastructural analysis has recently shown that the cellular organelles move to the perinuclear region on one side of the cells at the early stages of infection (Goldsmith et al. 2004, Monaghan et al. 2004, Novoa et al. 2005). Ng \& Hong (1989) also reported that the proliferation of the RER is the earliest visible event after Kunjin virus infection (also reviewed by Novoa et al. 2005). Thus, the characteristic distribution and proliferation of the cellular organelles observed in our work suggests that TSV replication might take place in a defined region of the cytoplasm.

Additionally in our study, TEM analysis at a high magnification revealed that SMVs were generated within the cytosol of TSV-infected cells (Fig. 2b). The cluster of SMVs consisted of numerous vesicles and was surrounded by distended RER that contained electron-dense materials. The induction and proliferation of these unique cytoplasmic membrane structures have been previously described as convoluted membranes, paracrystalline arrays, and small vesicular structures or vesicle packets (Mackenzie 2005). More importantly, replication of flaviviruses such as Kunjin virus, West Nile virus (WNV), and tick-borne encephalitis virus, is believed to take place in the membrane structures (Hong \& Ng 1987, Ng et al. 1994,
Lorenz et al. 2003). The proximity between the clustered SMVs and the RER as illustrated in Figs. 2b, 3, \& $8 \mathrm{~d}$ also suggests an association between these 2 structures. For poliovirus, the replication complex has also been shown to occur within ER-derived vesicles (Rust et al. 2001), while the replication of flaviviruses has been reported to take place in Golgi-derived vesicles (Mackenzie et al. 1999).

Our results obtained by ISH are in accordance with those illustrated by TEM. A positive reaction to TSVspecific gene probes was seen in close association with the membranous structures (Figs. $7 \& 8$ ). These confirmed that the viral RNA is associated with the proliferating membranes. Unlike the RER and SMVs, mitochondria may not be directly involved in the biosynthesis of TSV RNA genomes because they did not react to the TSV-specific gene probes by ISH (Fig. 7). However, the significant accumulation of mitochondria in the cytosol at early to mid stages of TSV infection (Figs. $1 \& 2$ ) and their presence within intracellular inclusion bodies and the perinuclear region (Fig. $7 \mathrm{e}, \mathrm{f}$ ) suggest that they actively participate in the formation of viral replication complex. Miller et al. (2001) demonstrated that flock house virus RNA replicates on outer mitochondrial membranes, and Novoa et al. (2005) suggested that mitochondria, cytoplasmic membranes, and cytoskeletons supply factors for key steps of the viral replication.

Replication of all RNA viruses is believed to take place exclusively within the cytoplasm. However, recent studies have shown that a significant proportion $(20 \%)$ of the total RNA-dependent RNA polymerase (RdRp) activity from cells infected with dengue virus, Japanese encephalitis virus (JEV), and WNV is resident within the nucleus; furthermore, the major replicase proteins of JEV also localized within the nucleus by confocal microscopy and IEM (Uchil et al. 2006). Therefore, the host cell nucleus clearly functions as an additional site for the replication of flaviviruses. In the present study, a positive reaction by ISH was evident in between the inner and outer nuclear membranes (Figs. 7a,c, 8a,c, \& 9). These results implicate an accumulation and association of TSV RNA with the nuclear membrane, although the viral particles were not seen within the nucleus by TEM or ISH. In addition, the findings indicate that additional studies will be needed to elucidate the presence of functionally active TSV RNA synthesis within the host cell nucleus or in association with the nuclear membrane.

Following TEM, inclusion bodies were frequently observed, and they occupied a large area within the cytoplasm of TSV-infected cells (Figs. 1, 2, \& 3). Unfortunately, we were unable to identify immature or mature TSV particles within the inclusion bodies stained only with UA and $\mathrm{LC}_{i}$ however, the results in 
Fig. 8e demonstrated that the TSV RNA genomes were present within the inclusion bodies because the viral genomes reacted to the TSV-specific gene probes by ISH. More intriguingly, TSV particles seen as spherical bodies were observed by TEM (Fig. 4), and following EM-ISH, they were seen with gold particles near the vesicular membranes (Fig. 9). Thus, these results confirmed that the cellular membranes carry TSV RNA genomes and that they are important for the morphogenesis and propagation of TSV.

In conclusion, infection by TSV results in alterations of intracellular membranes within the cytosol. We demonstrated here by TEM and EM-ISH that TSV RNA genomes and TSV particles are associated with the proliferating membranes. Further characterization on cellular origin and biochemical compositions of these vesicular membranes will shed light on biogenesis and propagation strategy of TSV in infected shrimp cells.

Acknowledgements. This work was supported by the Gulf Coast Research Laboratory Consortium Marine Shrimp Farming Program, CSREES, USDA, Grant no. 2002-38808-01345. T.S. was supported by a scholarship from the Royal Government of Thailand. We thank D. L. Bentley and Dr. K. F. J. Tang for technical assistance.

\section{LITERATURE CITED}

Bonami JR, Lightner DV, Redman RM, Poulos BT (1992) Partial characterization of a Togavirus (LOVV) associated with histopathological changes of the lymphoid organ of penaeid shrimps. Dis Aquat Org 14:145-152

Bonami JR, Hasson KW, Mari J, Poulos BT, Lightner DV (1997) Taura syndrome of marine penaeid shrimp: characterization of the viral agent. J Gen Virol 78:313-319

Goldsmith CS, Tatti KM, Ksiazek TG, Rollin PE and 6 others (2004) Ultrastructural characterization of SARS coronavirus. Emerg Infect Dis 10:320-326

Gosert R, Kanjanahaluethai A, Egger D, Bienz K, Baker SC (2002) RNA replication of mouse hepatitis virus takes place at double-membrane vesicles. J Virol 76:3697-3708

Gosert R, Egger D, Lohmann V, Bartenschlager R, Blum HE, Bienz K, Moradpour D (2003) Identification of the hepatitis C virus RNA replication complex in Huh-7 cells harboring subgenomic replicons. J Virol 77:5487-5492

Grief C, Galler R, Cortes LM, Barth OM (1997) Intracellular localization of dengue-2 RNA in mosquito cell culture using electron microscopic in situ hybridization. Arch Virol 142:2347-2357

Hasson KW, Lightner DV, Poulos BT, Redman RM, White BL, Brock JA, Bonami JR (1995) Taura syndrome in Penaeus vannamei: demonstration of a viral etiology. Dis Aquat Org 23:115-126

Hong SS, Ng ML (1987) Involvement of microtubules in Kunjin virus replication. Arch Virol 97:115-121

Krogerus C, Egger D, Samuilova O, Hyypia T, Beinz K (2003) Replication complex of human parechovirus 1. J Virol $77: 8512-8523$

Kujala P, Ikaheimonen A, Ehsani N, Vihinen H, Auvinen P, Kaariainen L (2001) Biogenesis of the Semliki Forest virus
RNA replication complex. J Virol 75:3873-3884

Lightner DV (1996) A handbook of shrimp pathology and diagnostic procedures for diseases for cultured penaeid shrimp. World Aquaculture Society, Baton Rouge, LA

Lightner DV, Redman RM, Hasson KW, Pantoja CR (1995) Taura syndrome in Penaeus vannamei (Crustacea: Decapoda): gross signs, histopathology and ultrastructure. Dis Aquat Org 21:53-59

Lorenz IC, Kartenbeck J, Mezzacasa A, Alison SL, Heinz FX, Helenius A (2003) Intracellular assembly and secretion of recombinant subviral particles from tick-borne encephalitis virus. J Virol 77:4370-4382

Mackenzie J (2005) Wrapping things up about virus RNA replication. Traffic 6:967-977

Mackenzie JM, Jones MK, Westaway EG (1999) Markers for trans-Golgi membranes and the intermediate compartment localize to induced membranes with distinct replication functions in flavivirus-infected cells. J Virol 73: 9555-9567

Magliano D, Marshal JA, Bowden DS, Vardaxis N, Meanger J, Lee JY (1998) Rubella virus replication complexes are virus-modified lysosomes. Virology 240:57-63

Mari J, Bonami JR, Lightner DV (1998) Taura syndrome of penaeid shrimp: cloning of viral genome fragments and development of specific gene probes. Dis Aquat Org 33: $11-17$

Mari J, Poulos BT, Lightner DV, Bonami JR (2002) Shrimp Taura syndrome virus: genomic characterization and similarity with members of the genus Cricket paralysis-like viruses. J Gen Virol 83:915-926

Mayo MA (2005) Changes to virus taxonomy 2004. Arch Virol 150:189-198

Miller DJ, Schwartz MD, Ahlquist P (2001) Flock house virus RNA replicates on outer mitochondrial membranes in Drosophila cells. J Virol 75:11664-11676

Monaghan P, Cook H, Jackson T, Ryan M, Wileman T (2004) The ultrastructure of the developing replication site in foot-and-mouth disease virus-infected BHK-38 cells. J Gen Virol 85: 933-946

Morel G, Cavalier A, Williams L (2001) In situ hybridization in electron microscopy. CRC Press, Boca Raton, FL, p 144-145

Moss SM, Doyle RW, Lightner DV (2005) Breeding shrimp for disease resistance: challenges and opportunities for improvement. In: Walker $\mathrm{P}$, Lester R, Bondad-Reantaso MG (eds) Diseases in Asian aquaculture V. Asian Fisheries Society, Manila, p 379-393

Ng ML, Hong SS (1989) Flavivirus infection: essential ultrastructural changes and association of Kunjin virus NS3 protein with microtubules. Arch Virol 106:103-120

Ng ML, Teong FM, Tan SH (1994) Cryosubstitution technique reveals new morphology of flavivirus-induced structures. J Virol Methods 49:305-314

Nielsen L, Sang-oum W, Chavadhanarak S, Flegel TW (2005) Taura syndrome virus (TSV) in Thailand and its relationship to TSV in China and the Americas. Dis Aquat Org 63:101-106

Novoa RR, Calderita G, Arranz R, Fontana J, Granzow H, Risco C (2005) Virus factories: associations of cell organelles for viral replication and morphogenesis. Biol Cell 97:147-172

OIE (Organisation Mondiale de la Santé Animale) (2006) Aquatic animal health code. OIE Aquatic Animals Commission, Paris. Also available at: www.oie.int/eng/ normes/en_acode.htm

Pérez-Farfante I, Kensley BF (1997) Penaeoid and sergestoid shrimp and prawns of the world: keys and diagnoses for the families and genera. Mem Mus Natl Hist Nat 175: $1-233$ 
Rust RC, Landmann L, Gosert R, Tang BL, Hong W, Hauri HP, Egger D, Bienz K (2001) Cellular COPII proteins are involved in production of the vesicles that form the poliovirus replication complex. J Virol 75:9808-9818

Pantoja CR, Lightner DV (2001) Detection of hepatopancreatic parvovirus (HPV) of penaeid shrimp by in situ hybridization at the electron microscope level. Dis Aquat Org 44:87-96

Srisuvan T, Tang KFJ, Lightner DV (2005) Experimental infection of Penaeus monodon with Taura syndrome virus (TSV). Dis Aquat Org 67:1-8

Editorial responsibility: Timothy Flegel,

Bangkok, Thailand
Srisuvan T, Noble BL, Schofield PJ, Lightner DV (2006) Comparison of four Taura syndrome virus (TSV) isolates in oral challenge studies with Litopenaeus vannamei unselected or selected for resistance to TSV. Dis Aquat Org 71:1-10

Tang KF, Lightner DV (2005) Phylogenetic analysis of Taura syndrome virus isolates collected between 1993 and 2004 and virulence comparison between two isolates representing different genetic variants. Virus Res 112:69-76

Uchil PD, Kumar AVA, Satchidanandam V (2006) Nuclear localization of flavivirus RNA synthesis in infected cells. J Virol 80:5451-5464

Submitted: August 1, 2006; Accepted: September 29, 2006 Proofs received from author(s): November 27, 2006 